\title{
PERLINDUNGAN HUKUM TERHADAP PROFESI NOTARIS DALAM PEMBUATAN PARTIJ AKTA
}

\author{
Subiyanto \\ Notaris dan PPAT Kabupaten Jombang \\ notarissubiyanto345@yahoo.com
}

\begin{abstract}
The legal acts clients who come to the notary. Formulated into an authentic deed in accordance with the authority of a notary, and then the notary made the deed at the request of the client. Therefore, the notary must ensure that the deed made it complies according to the legal rules that have been determined, so that the interests of concered are protected with such deed. A notarial deed is an authentic deed made according to the forms and procedures set in this constitution. Notary bound with the truth formil because of the liability according UUJN, if the parties dispute, so notary can not be punished.
\end{abstract}

Keywords: Legal Acts, the Parties Dispute, A Notarial Deed, Notary.

\begin{abstract}
Abstrak
Terjadinya perbuatan hukum penghadap datang ke Notaris diformulasikan ke dalam akta otentik sesuai dengan kewenangan Notaris, dan kemudian Notaris membuatkan akta atas permintaan para penghadap tersebut, Oleh karena itu Notaris harus menjamin bahwa akta yang dibuat tersebut telah sesuai menurut aturan hukum yang sudah ditentukan, sehingga kepentingan yang bersangkutan terlindungi dengan akta tersebut. Akta Notaris adalah akta otentik yang dibuat menurut bentuk dan tata cara yang ditetapkan dalam undang-undang ini. Notaris terikat dengan kebenaran formil karena kewajiban menurut UUJN. Jika para pihak bersengketa, maka notaris tidak bisa dihukum.
\end{abstract}

Kata kunci : Perbuatan Hukum, Para Pihak, Akta Notaris, Notaris

\section{A. Pendahuluan}

Istilah perikatan dalam bahasa Belanda disebut dengan istilah verbintenis atau verbinden yang artinya mengikat, verbintenis menunjuk pada adanya "Ikatan" atau "hubungan" sehingga verbintenis diartikan sebagai hubungan hukum. Oleh karena itu, istilah verbintenis lebih tepat diartikan sebagai istilah perikatan. ${ }^{1}$

Perjanjian merupakan sumber dari perikatan/ verbintenis, yang lahir bisa berasal dari perjanjian maupun berasal dari undangundang, Perjanjian/overeenkomst yang sah harus memenuhi syarat-syarat tertentu yang mengandung unsur-unsur essentialia. Naturalia, dan accindentalia yang berasas konsensualitas, freedom of contract serta, pacta sunt servanda.

1 Wawan Muhwan Hariri, 2011, Hukum Perikatan, Pustaka Setia, Bandung, hlm. 15.
Prinsip pacta sunt servanda secara harfiah berari "janji itu mengikat " yang dimaksudkan adalah bahwa jika suatu kontrak sudah dibuat secara sah oleh para pihak, maka kontak tersebut sudah mengikat para pihak. Bahkan mengikatnya kontrak yang dibuat para pihak tersebut sama kekuatannya dengan mengikatnya sebuah undang-undang yang dibuat oleh parlemen dan Pemerintah. ${ }^{2}$

Indonesia menganut sistim hukum Civil Law, mengenal asas kebebasan berkontrak, sebagaimanan ditentukan dalam Pasal 1338 ayat (1) Kitab Undang-Undang Hukum Perdata, menyimpan pengertian asas pacta sunt servanda yaitu perjanjian yang telah disepakati berlaku sebagai undang-undang bagi para pihak yang

2 Munir Fuady, 2003, Hukum Kontrak, Citra Aditya Bakti, Bandung, hlm. 50. 
bersangkutan. $^{3}$

Bahwa hukum perjanjian menganut sistem terbuka atau beginsel der controctsvrujheid, sehingga seolah-olah dalam membuat perjanjian diperbolehkan membuat perjanjian apa saja dan itu akan mengikat sebagaimana berupa apa yang dinamakan "ketertiban dan kesusilaan umum". ${ }^{4}$ Suatu kontrak atau perjanjian harus memenuhi syarat sahnya suatu perjanjian, yaitu sepakat, kecakapan, hal tertentu, dan suatu sebab yang halal, sebagaimana ditentukan dalam Pasal 1320 Kitab Undang-Undang Hukum Perdata maka suatu perjanjian menjadi sah dan mengikat secara hukum bagi para pihak yang membuatnya. ${ }^{5}$

Perjanjian harus dilaksanakan dengan etiket baik (vide 1338 ayat (3) Kitab Undang-Undang Hukum Perdata, sedangkan suatu perikatan adalah perhubungan hukum antara antara 2 (dua) orang atau 2 (dua) pihak, berdasarkan mana pihak yang satu berhak menuntut sesuatu hal dari pihak yang lain, dan pihak yang lain berkewajiban untuk memenuhi tuntutan itu. ${ }^{6}$

Dalam ilmu hukum Perdata, Perikatan adalah suatu hubungan hukum yang berkaitan dengan harta kekayaan yang dilakukan 2 (dua) orang atau lebih atau sebagai para pihak yang melakukan ikatan hukum, yang satu atas sesuatu dan pihak lain berkewajiban atas sesuatu. ${ }^{7}$

Perjanjian perikatan jual beli (P.P.J.B) lunas dengan kuasa pada peralihan hak milik atas tanah ini menitik beratkan pada otentisitas akta yang dibuat Notaris yang objeknya jual beli hak milik atas tanah dalam Hermeutika hukum dianalogikan seperti akta jual beli yang dibuat Pejabat PembuatAkta Tanah (P.P.A.T), supaya memeliki kepastian hukum dan perlindungan hukum maka didaftarakan pada Kantor Pertanahan sewilayah kerja Notaris. Salah satu hak atas tanah menurut hukum adat yang merupakan induk dari

3 J.B. Daliyo, dkk, 1994, Pengantar IImu Hukum, Gramedia Pustaka Utama, Jakarta, hIm. 89.

4 R.Subekti, 1985, Aneka Perjanjian, Cetakan VII, Alumni, Bandung, hIm. 5.

5 J.B. Daliyo, dkk, Pengantar IImu Hukum, Op. Cit, hlm. 104.

6 R.Subekti, 1990, Hukum Perjanjian, Inter Masa, Jakarta, hlm. 1.

7 Wawan Muhwan Hariri, Hukum Perikatan,Op.Cit, hIm. 15. hak-hak atas tanah lainya dan merupakan hak atas tanah yang pertama kali sebelum dikenal adanya hak-hak perorangan atas tanah adalah, hak ulayat. ${ }^{8}$

Dalam kontek perjanjian ini adalah jual beli hak milik atas tanah, dimaksud dalam hal ini dibatasi pembahasannya adalah hak milik karena terjadinya hak milik berasal dari adanya hubungan hukum yang dituangkan dalam suatu akta otenrtik, sedangkan objeknya adalah hak milik atas tanah yang menurut undang-undang bisa berasal dari konfersi hak eingendom menjadi hak milik maupun yang sudah timbul hak milik, dan terjadinya hak milik karena penetapan Pemerintah yaitu pemberian hak milik atas tanah Negara seperti Hak Guna Bangunan. Adapun jual beli adalah suatu perjanjian dengan mana pihak satu mengikat dirinya untuk menyerahkan hak milik atas suatu barang dan pihak yang lain untuk membayar harga yang telah diperjanjikan. ${ }^{9}$

Berdasarkan prinsip kebebasan berkontrak (freedom of contract) adalah para pihak dalam suatu kontrak bebas untuk membuat tidak memuat kontrak dan kebebasan mengatur isi kontrak selama tidak bertentangan hukum yang berlaku, kebebasan berkontrak adalah salah satu asas yang sangat penting di dalam hukum perjanjian. Kebebasan ini adalah perwujudan dari kehendak bebas pancaran hak asasi manusia, (vide UndangUndang Nomor 39 Tahun 1999 Pasal 1 tentang Hak Asassi Manusia), ${ }^{10}$ perjanjian timbal balik adalah perjanjian yang menimbulkan kewajiban pokok bagi kedua belah pihak. Misalnya perjanjian jual beli. ${ }^{11}$ Yang dimasudkan dalam perjanjian jual beli di dalam penelitian ini adalah jual beli tanah dan apa-apa yang berdiri di atasnya sebagai atau menurut hukum dianggap sebagai benda tetap yang timbul dalam perjanjian ini adanya konsensus yang mempunyai kekuatan mengikat dituangkan ke dalam membuat sebuah kontrak yang meninbulkan kewajiban.

Jual beli menurut satu (si penjual) berjanji untuk menyerahkan hak milik atas suatu barang,

8 Muhammad Bakri, 2011, Hak Penguasaan Tanah oleh Negara, UB press, hlm. 15.

9 Subekti, Hukum Perjanjian, Op. Cit, hlm. 79.

10 Mariam Darus Badrulzaman,dkk, 2001, Kompilasi Hukum Perikatan, Citra Aditya Bakti, Bandung, hlm. 84.

11 Ibid., hlm. 66. 
sedang pihak yang lainnya (si pembeli) berjanji untuk untuk membayar harga yang terdiri atas sejumlah uang sebagai imbalan hak milik tersebut. ${ }^{12}$ Pada saat terjadinya jual beli unsur-unsur pokok ada barang dan harga (essentialia), sesuai asas "konsensualime" yang menjiwai hukum perjanjian Burgerlijk Wetboek (B.W). Perjanjian jual beli itu sudah dilahirkan pada detik tercapainya "sepakat" mengenai barang dan harga. ${ }^{13}$ Supaya mengikat (vide 1338 Kitab Undang-Undang Hukum Perdata) kewajiban penyerahan hak milik benda tidak bergerak "Tanah" memiliki arti lapisan bumi atau lapisan bumi yang di atas sekali. ${ }^{14}$ Karena sudah terjadi peralihan hak yaitu hak milik absolute menurut hukum perdata terjadi hubungan hukum. Hubungan hukum ialah hubungan antara subjek hukum yang diatur oleh hukum, isinya adalah hak dan kewajiban bagi masing-masing pihak. ${ }^{15}$ Supaya jual beli ini sah menurut Undang-Undang dapat dituangkan pada akta otentik yang dibuat di hadapan Notaris yaitu otentisitas akta "P.P.J.B lunas dengan Kuasa".

Sedang Hak dan kewajiban dalam hubungan hukum timbal balik antara penjual dan pembeli dalam fakta yuridis karena terjadinya hak penguasaan, adalah hak yang memberi wewenang kepada pemegang hak untuk berbuat tanah yang dikuasainya. ${ }^{16}$

Dalam ruang lingkup agraria, tanah merupakan bagian dari bumi, yang disebut permukaan bumi. Tanah yang dimasudkan di sini bukan mengatur tanah dalam segala aspeknya, melainkan hanya mengatur salah satu aspeknya, yaitu dalam pengertian yuridis yang disebut hak. ${ }^{17}$ Terjadi fakta hukum perdata yaitu adanya transaksi jual beli dengan objek hak milik atas tanah, sehingga berakibat timbulnya peralihan hak kepemilikan absolute. Undang-Undang Nomor 5 tahun 1960 tentang Pokok-Pokok Agraria Pasal 20 ayat (2)

12 R.Subekti, 1995, Aneka Perjanjian, Citra Aditya Bakti, Bandung, hlm. 1.

13 R.Subekti, Aneka Perjanjian, Ibid., hlm. 2.

14 H. Suko Wiyono, 2010, Hukum Pertanahan, Bayumedia Publishing, Malang, hlm.7.

15 J.B. Daliyo, dkk, Pengantar IImu Hukum, Loc. Cit, hlm. 104.

16 H. Suko Wiyono, Hukum Pertanahan, Op.Cit., hlm. 2.

17 Urip Santoso, 2012, Hukum Agraria, Kajian Komprehensif, Kencana Prenada Media Group, Jakarta, hIm. 9. hak milik dapat beralih dan dialihkan kepada pihak lain. ${ }^{18}$ Menurut Undang-Undang, akta otentik yang dibuat di hadapan Notaris sebagai pejabat umum sesuai kewenangannya membuat akta yang berkaitan dengan pertanahan, (vide Undang-Undang nomor 2 Tahun 2014 tentang Jabatan Notaris Pasal 15 ayat (2) huruf "f"). Peralihan hak milik atas tanah terjadi melalui secara derivative suatu subjek hukum memperoleh tanah dari subjek hukum lain yang semula sudah berstatus hak tanah milik, misalnya jual beli. ${ }^{19}$

Subjek hukum yang dapat mempunyai hak milik atas tanah menurut Pasal 21 U.U.P.A yaitu:

a) Warga Negara Indonesia.

b) Badan - badan hukum tertentu.

c) Badan-badan hukum yang bergerak dalam lapangan sosial dan keagamaan sepanjang tanahnya dipergunakan untuk itu. ${ }^{20}$

Dari penjelasan tersebut di atas, maka akan dibahas mengenai bagaimana Perlindungan Hukum Terhadap Profesi Notaris Dalam Pembuatan Partij Akta?

\section{B. Pembahasan}

Terjadinya perbuatan hukum atau peristiwa hukum tersebut hak milik atas tanah sudah beralih ke subjek hukum yang satu kepada subjek hukum yang lain, hal ini tentu saja ada hubungan hukum antara pejabat umum yang melegalkan akta otentik dengan para pihak. Ketika penghadap datang ke Notaris agar tindakan atau perbuatannya diformulasikan ke dalam akta otentik sesuai dengan kewenangan Notaris, dan kemudian Notaris membuatkan akta atas permintaan atau keinginan para penghadap tersebut, maka dalam hal ini memberikan landasan kepada Notaris dan para penghadap telah terjadi hubungan hukum. Oleh karena itu Notaris harus menjamin bahwa akta yang dibuat tersebut telah sesuai menurut aturan hukum yang sudah ditentukan, sehingga kepentingan yang bersangkutan terlindungi

18 Subekti, 2008, Kitab Undang-Undang Hukum Perdata, Pradnya Paramita, Jakarta, hlm. 622.

19 Urip Santoso, Hukum Agraria, Kajian Komprehensif, Op. Cit., hlm. 98.

20 Eddy Ruchiyat, 2006, Politik Pertanahan Nasional Sampai Orde Reformasi, Alumni, Bandung, hlm. 53. 
dengan akta tersebut. ${ }^{21}$ Akta Notaris adalah akta otentik yang dibuat oleh Notaris menurut bentuk dan tata cara yang ditetapkan dalam undang-undang ini. ${ }^{22}$ Yaitu kepala akta yang menyangkut nomor, tanggal dan waktu akta saat akta dibuat, nama pejabat, wilayah hukumnya, dan identitas para penghadapnya yang menjadi syarat subjektif, badan akta terdiri dari isi akta menjadi syarat obektif dan akhir akta yang terkait dengan dibacakan isi akta serta dibubuhkan tanda tangan dan jap jari penghadap, saksi dan Notaris.

Perjanjian perikatan tersebut jual beli tanah tersebut telah memenuhi syarat subjektif dan objektif sesuai ketentuan Pasal 1320 Kitab Undang-Undang Hukum Perdata, para pihak sepakat di hadapan Notaris untuk melakukan perbuatan hukum jual beli hak milik atas tanah. (Vide Pasal 16 ayat(1) huruf a juncto Pasal 20 ayat (1 dan 2) Undang-Undang Pokok Agraria). ${ }^{23} \mathrm{Hal}$ ini kewenangan notaris dalam membuat akta yang berkaitan dengan pertanahan sesuai Undang-Undang Nomor 30 Tahun 2004 tentang Jabatan Notaris yang diubah menjadi Undang-Undang Nomor 2 Tahun 2014 Pasal 15 ayat (2) huruf $f$, maka jual beli hak milik atas tanah dapat dilaksanakan di Notaris dalam bentuk perbuatan hukum yang dituangkan di akta otentik P.P.J.B dengan klausul pokok pembayaran lunas disertai kuasa. Dalam hal ini peristiwa hukum yang dilakukan pada akta P.P.J.B Lunas dengan kuasa dimana penjual memberi kuasa khusus yang kekuatan hukumnya menyimpang dari Pasal 1813 Kitab Undang-Undang Hukum Perdata (KUHPerdata) terhadap objek tanah yang dimaksud dimana penjual untuk melakukan tindakan hukum guna melepaskan haknya kepada pembeli tidak terbatas waktu dan meninggalnya si penjual, hal ini dimaksudkan supaya pembeli kapan saja waktunya tetap dapat melakukan perbuatan hukum untuk pendaftaran tanah kapan saja waktunya setelah memnuhi kewajiban pajak dan

21 Habib Adjie, 2011, Hukum Notaris Indonesia, Refika Aditama, Bandung, hlm. 16.

22 Undang-Undang Nomor 30 Tahun 2004, Citra Umbara, Bandung, hlm. 3.

23 R. Subekti, Undang-Undang Pokok Agraria, Pradnya Paramita, Jakarta, hlm. 520.
P.N.B.P, dengan artian tidak ada kuasa apabila tidak ada akta P.P.J.B lunas yang melekat tidak terpisahkan keduanya dan isinya termasuk juga hal ini untuk menandatangani berkas-berkas terkait yang akan digunakan untuk pendaftaran tanah melalui akta yang dibuat pejabat Notaris. Berdasarkan Undang-Undang Nomor 2 tahun 2014 tentang Jabatan Notaris Pasal 1 ayat (1) disebutkan, Notaris adalah pejabat umum yang berwenang membuat akta otentik dan kewenangan lainnya sebagai dimaksud dalam Undang-Undang ini. ${ }^{24}$

Istilah Pejabat umum merupakan terjemah dari istilah Openbare Amtbtenaren yang terdapat dalam Pasal 1 Peraturan Jabatan Notaris dan Pasal 1868 Burgerlijk Wetboek (B.W), Pasal 1 Peraturan Jabatan Notaris menyebutkan bahwa:

De notarissen zijn openbare ambtenaren uitsluitend bevoegd, om authentieke akten op te bereene algemeene verordening gebiedt of debelanghebbenden veriangen, reksels uit te geven; alles voorzoover het opmaken dier akten door eene algemeene verordening niet ook aan andere ambtenaren of personen opgedragen of voorhebehouden is,

Dijelaskan Notaris adalah Pejabat yang satu-satunya berwenang untuk membuat akta otentik mengenai semua perbuatan, perjanjian dan penetapan yang diharuskan oleh suatu peraturan umum atau oleh yang berkepentingan dikehendaki untuk dinyatakan dalam suatu akta otentik, menjamin kepastian tanggalnya, menyimpan aktanya dan memberikan grosse, salinan dan kutipannya, semuanya sepanjang pembuatan akta itu oleh suatu peraturan umum tidak juga ditugaskan atau dikecualikan kepada pejabat atau orang lain, dan Pasal 1868 Burgerlijk Wetboek (B.W) menyebutkan:

Eene authentieke acte is de zoodanige welke in de wettelijken vorn is verleden, door of ten overstaan van openbare ambtenaren die daartoe bevoegd zijn terplaatse alwaar zulks is geschied.

Artinya suatu akta otentik ialah suatu akta yang dibuat dalam bentuk yang ditentukan undang-undang oleh atau di hadapan pejabat 24 Undang-Undang Nomor 30 Tahun 2004, Ibid., hIm. 2. 
umum yang berwenang untuk itu di tempat akta itu dibuat. ${ }^{25}$

Dari ketentuan dalam Pasal 1868 B.W tersebut suatu akta dapat dikatakan sebagai akta otentik apabila memenuhi syarat sebagai berikut:

1. Akta tersebut dibuat oleh (door) atau dibuat dihadapan (ten overstaan) seorang pejabat umum (openbare ambtenaren).

2. Akta tersebut harus dibuat dalam bentuk (vorm) yang telah ditentukanoleh undangundang (wettelikj/'e vorm).

3. Pejabat umum yang membuat akta harus mempunyai kewenangan untuk membuat akta tersebut, baik kewenangan berdasarkan daerah (wilayah) kerjanya atau waktu pada saat akta tersebut dibuat. ${ }^{26}$

Suatu akta otentik bentuknya sudah ditentukan sedemikian rupa menurut Undang-Undang, pada saat itu para pihak menghadap/ dihadapan seorang pejabat umum pada wilayah tertentu dimana akta otentik tersebut dibuat sehingga sarat subjektif dan objektif serta terpenuhi uji materiil dan formilnya.

Otentisitas akta P.P.J.B lunas dengan kuasa terkandung di dalam Pasal 1868 K.U.H. Perdata apabila diimplementasikan ke dalam UndangUndang Republik Indonesia Nomor 2 Tahun 2014 tentang Jabatan Notaris maka Notaris sebagai pejabat umum berdasarkan Pasal 1 ayat (1), bentuk (vorm) aktanya Notaris berdasarkan Pasal 38 ayat (1) yaitu ditentukan sedemikian tersusun terdiri dari awal akta atau kepala akta, badan akta/ isi akta, akhir atau penutup akta merupakan akta otentik mempunyai daya pembuktianya sempurna dan kewenangannya Notaris berdasarkan Pasal 1 ayat (7) dan wilayah hukum menghadap kepada pejabatnya.

Apabila Peristiwa hukum jual beli hak milik atas tanah (vide Peraturan Pemerintah Republik Indonesia nomor 37 tahun 1998 Pasal 2 ayat (2) huruf a.) diimplemtasikan ke dalam Akta Jual Beli ( A.J.B ) vide Pasal 1 ayat (4) yang dilakukan oleh Pejabat Pembuat Akta Tanah (P.P.A.T) dan

25 Habib Adjie, 2009, Sekilas Dunia Notaris \& P.P.A.T, Mondar Maju, Bandung, hlm. 15.

26 H.Husni Thamrin, 2011, Pembuatan Akta Pertanahan Oleh Notaris, Laksbang Pressindo, Yogyakarta, hlm. 23. bentuk aktanya ditentukan oleh Menteri (vide Pasal 21 ayat (1) serta kewenangannya tidak didasarkan Undang-Undang (vide KUHPerdata 1868), maka aktanya tidak otentik sehingga daya pembuktianya kekuatanya hukumnya seperti akta dibawah tangan. Dalam hal ini otentisitas akta P.P.A.T dalam perspektif hukum di Indonesia harus dibuat di hadapan pejabat umum dan belum pernah disebut dalam Undang-Undang, dan otentiknya suatu akta P.P.A.T bentuknya ditentukan oleh peraturan Menteri. Peraturan Pemerintah Republik Indonesia Nomor 37 Tahun 1998 tentang Peraturan Jabatan Pejabat Pembuat Akta Tanah Pasal 21 ayat (1). ${ }^{27}$ Apabila dicermati asas berlakunya Undang-Undang hukum kita, Undang-Undang yang lebih tinnggi menggugurkan peraturan dibawanya (lex supriori derogate lex inferiori ). Maka dalam asas hukum kita dikenal, undang-undang yang berlaku kemudian membatalkan undang-undang terdahulu, sejauh undang-undang itu mengatur objek yang sama (lex posterior derogat legi priori). ${ }^{28}$

Undang-Undang Nomor 2 Tahun 2014 tentang Jabatan Notaris Pasal 1 ayat (1). Notaris adalah pejabat umum yang berwenang untuk membuat akta otentik dan kewenangan lainya sebagai mana dimaksud dalam undangundang ini, ${ }^{29}$ melihat 2 (dua) azas hukum kita yang disebutkan di atas, maka hal ini dapat terjadi konflik norma, kekaburan hukum yang menyangkut kewenangan pembuatan akta otentik mengarah pada dissinkronisasi atau inkonsistensi pelaksanaan hukum positif (ius constitutum) Negara Indonesia.

Philipus. M. Hadjon. ${ }^{30}$ menjelaskan kewenangan itu diperoleh melalui 3 (tiga) sumber, yaitu: atribusi, delegasi dan mandat. Kewenangan atribusi pada lazimnya digariskan melalui pembagian kekuasaan Negara oleh Undang-Undang Dasar, sedang kewenangan delegasi dan mandat adalah kewenangan yang

27 Boedi Harsono, 2008, Hukum Agraria Indonesia, Himpunan Peraturan-Peraturan Hukum Tanah, Djambatan, Jakarta, hlm. 695.

28 J.B. Daliyo, dkk, Pengantar IImu Hukum, Loc. Cit., hlm. 55.

29 Undang-Undang Nomor 30 Tahun 2004, Op.Cit., hlm. 2

30 H. Husni Thamrin, Pembuatan Akta Pertanahan Oleh Notaris, Op. Cit., hlm. 67. 
berasal dari pelimpahan. Setiap kewenangan yang dimiliki organ/pejabat pemerintah dibatasi oleh isi/materi, wilayah, maupun waktu. Cacat dalam aspek-aspek tersebut menimbulkan cacat kewenangan (onbevoegdheid) yang menyangkut: (a) cacat isi (onbevoegd heid ratione materiae); (b) cacat wilayah (onbevoegdheid); (c) cacat waktu (onbevoegdheid). (Philipus. M. Hadjon), mengatakan bahwa P.P.A.T (1) sumber kewengannya tidak didasarkan pada sumber yang sah artinya tidak didasarkan undang-undang, (2) bahwa sebagai pejabat umum (openbaar ambtenaar) pengangkatannya tidak dilakukan oleh Kepala Negara bukan oleh menteri, (3) bentuk aktanya diatur oleh menteri bukan peraturan perundang-undangan, sehingga tidak memenuhi sebagaimana yang dimaksud didalam Pasal 1886 B.W dan U.U.J.N Pasal 1 (ayat) 1. Menurut Undang-Undang Nomor 10 Tahun 2004, peraturan menteri bukan termasuk tata urutan peundang-undangan, (4) kewenangan yang diberikan berdasarkan P.P Nomor 24 Tahun 1997 jo P.P 37 Tahun 1998 ketentuan tersebut kewenangannya di bawah Undang-Undang Nomor 30 Tahun 2004 tentang Jabatan Notaris yang salah satu kewenangannya diatur di Pasal 15 ayat (2) huruf $f$ ).

Maka menurut asas hukum lex supriori derogate lex inferiori dan lex supriori derogate lex inferiori dan Undang-Undang Nomor 12 Tahun 2011 sehingga dapat disimpulkan dan digarisbawahi bahwa; (1) P.P.A.T tidak dapat membuatA.J.B yang berkaitan dengan pertanahan karena tidak sesuai dengan asas hukum administrasi, (2) kewengannya dalam membuat akta-akta pertanahan dikembalikan kepada Notaris berdasrkan U.U.J.N Pasal 15 (ayat) 2 huruff, Undang-Undang Nomor 2 Tahun 2014 tentang Jabatan Notaris, (3) untuk memberikan kepastian hukum dapat didaftarkan secara otomatis, (4) memberikan rasa keadilan dalam rangka asasi manusia membuat perbuatan hukum peralihan hak atas tanah melalui akta P.P.J.B lunas dengan kuasa dan (5) memberikan nilai kemanfatan bagi masyarakat luas se-provinsi wilayah kerja Notaris, (6) biaya relatif lebih murah karena memangkas birokrasi sehingga diharapkan dapat dijadikan produk hukum berlaku pada masa yang akan datang (ius constituendum) di kancah hukum pertanahan di Indonesia.
Akta yang dibuat Notaris merupakan alat bukti tertulis, oleh karena undang-undang diberikan kekuatan pembuktian yang sempurna. Menurut Pasal 165 H.I.R (Pasal 285 R.Bg serta Pasal 1870 dan 1871 B.W) akta otentik bagi para pihak dan ahli warisnya serta mereka yang memperoleh hak daripadanya merupakan alat bukti yang sempurna tentang apa yang termuat di dalamnya dan bahkan tentang apa yang terdapat dalam akta sebagai penuturan belaka yang terakhir ini hanya sepanjang apa yang diuraikan itu ada hubungannya langsung dengan pokok akta. ${ }^{31}$

Untuk itu akta otentik yang dibuat seorang Notaris sesuai dengan kewenangannya mempunyai kekuatan pembuktian yang kuat dan sempurna, karena selain para penghadap dibacakan dari isi kepala akta, badan akta, dan penutup atau akhir akta yang disaksikan sedikitnya 2 (dua) orang saksi, maka para penghadap, saksi dan pejabatnya membubuhkan tandatangannya serta melekatkan surat dan dokumen serta sidik jari penghadap pada minuta akta (Pasal 16 ayat (1) huruf c Undang-Undang Nomor 2 Tahun 2014 tentang Jabatan Notaris).

Akta dikatakan otentik sepanjang tidak dapat dibuktikan sebaliknya (asas acta publica probant sese ipsa) bahkan mempunyai kekuatan pembuktian lahiriah, artinya siapa yang mempersoalkan suatu akta, maka dia mempunyai beban pembuktian terhadap sangkalanya atas akta otentik tersebut (Pasal 138 H.I.R, 164 R.Bg, $148 \mathrm{Rv}$ ), maka dapat disimpulkan bahwa akta otentik dapat mempunyai kuatan pembuktian formil dimana kebenaran dari apa yang dilakukan pejabatnya dituangkan di dalam akta otentik serta kebenaran materiil dimana kebenaran suatu akta ditentukan dari isi akta tersebut atas dasar kemauan para pihak. Pada umumnya objek transaksi tanah sebagai barang tetap (tak bergerak) dengan perbuatan balik nama (overschrijving) di muka pegawai kadaster guna memberikan jaminan kepastian hukum terhadap transaksi jual beli tanah yang sudah terjadi levering/ peralihan hak atas tanah maka diperlukan pendaftaran tanah (vide Pasal 19 UUPA).

$31 \mathrm{H}$. Husni Thamrin, Pembuatan Akta Pertanahan Oleh Notaris, Loc. Cit., hlm. 31. 
Perjanjian timbal balik seperti jual beli harus ada "penyerahan atau levering" secara yuridis, antara lain penyerahan barang tak bergerak, dulu dibuat "akta transport" sejak berlakunya Undang-Undang Nomor 5 Tahun 1960 tentang Pokok-Pokok Agraria dibuat "akta jual beli (A.J.B)“ di hadapan Pejabat Pembuat Akta Tanah (P.P.A.T). ${ }^{32}$

Namun berjalannya waktu terjadi dinamika politik, hukum dipengaruhi politik, sehingga serta pengaturannya mempengaruhi tatanan kehidupan masyarakat berbangsa dan bernegara, sedangkan pendaftaran tanah diatur di dalam Peraturan Pemerintah Nomor 24 Tahun 1997 tentang Pendaftaran Tanah yang aturan pelaksanaanya diatur di dalam Peraturan Mentri Negara Agraria/Kepala BPN Nomor 3 Tahun 1997 yang kewenangannya dilakukan P.P.A.T berdasarkan Peraturan Pemerintah Nomor 37 Tahun 1998 tentang Peraturan Jabatan P.P.A.T.

Inilah potret inkonsistensi konstitusi kita tentang otentisitas akta dalam pendaftaran tanah harus diadakan singkronisasi jangan sampai cacat hukum seperti cacat kewenagan, cacat isi, cacat waktu dan cacat wilayahnya. Dari peraturan yang terkait dengan Pendaftaran Tanah semuanya berfokus pengunaan dengan istilah akta, akta tanah, akta P.P.A.T sebagai bukti telah dilaksanakan perbuatan hukum tertentu. Adapun namanya akta yang berkaitan dengan tanah adalah digunakan untuk memformulasikan untuk perbuatan, mengalihkan, memindahkan hak atas tanah. Bentuk akta-akta disebutkan di dalam Peraturan Mentri Negara Agraria/ Kepala B.P.N. Nomor 3 Tahun 1997 Pasal 95 ayat (1), antara lain A.J.B, sedangkan Pasal 37 Peraturan Pemerintah Nomor 24 Tahun 1997 juga disebutkan akta yang dibuat P.P.A.T meliputi antara lain jual beli. Untuk menjamin kepastian hukum terjadinya peralihan hak atas tanah dapat didaftarkan merupakan legal cadastre, yang bertujuan supaya tidak dapat diganggu gugat oleh pihak lain dengan artian Sertifikat Hak Milik atas tanah yang dibaliknama/peralihan hak di Kantor Pertanahan Kabupaten/ Kota dapat digunakan sebagai tanda bukti kepemilikanya yang sah biarpun di Indonesia menganut stelsel positif dan negatif, artinya bila sewaktu-waktu 32 R.Subekti, Hukum Perjanjian, Loc. Cit., hlm. 79. ditemukan data-data fisik dan yuridis yang menguatkan dianggap benar dapat mengubah untuk pembetulannya, dengan melakukan kegiatan-kegiatan sebagai yaitu:

1. Pengukuran, pemetaan dan pembukuan tanah.

2. Pendaftaran hak- hak atas tanah dan peralihan hak tersebut.

3. Pemberian surat-surat tanda bukti hak berlaku sebagai alat bukti yang kuat. ${ }^{33}$

Untuk kepentingan pendaftaran tanah ini, akan dilakukan menyimpang/ tidak dituangkan di dalam A.J.B yang menjadi Kewenangannya P.P.A.T., tapi lansung menggunakan akta otentik P.P.J.B lunas dengan kuasa yang menjadi kewenangan Notaris, dengan alasan karena bentuk formatnya akta otentik dibuat melalaui peraturan undangundang sedang A.J.B yang frormatnya dibuat oleh menteri (Permenag Agraria/Kepala BPN Nomor 3 Tahun 1997 Pasal 95 ayat (1) huruf a.), bahwa pendaftaran tanah dibuat dihadapan P.P.A.T. setempat pada objek tanah berada di wilayah hukum Kabupaten/ Kota, berdasarkan Peraturan Pemerintah Nomor 37 Tahun 1998 tentang Peraturan Jabatan Pejabat Pembuat Akta Tanah Pasal 2 tentang tugas pokok dan kewenangan P.P.A.T.

Moh. Mahfud MD. ${ }^{34}$ berpendapat, adapun produk hukum yang responsive adalah produk hukum yang pembentukannya atau pembuatannya dilakukan secara partisipatif dalam arti melibatkan masyarakat secara terbuka, muatanya bersifat aspiratif dalam arti menggambarkan kehendak umum masyarakat, dan cakupannya bersifat limitative dalam arti tak bisa ditafsirkan sembarangan secara sepihak melalui peraturan turunan oleh Pemerintah. Sebaliknya hukum yang presentatif atau ortodoks adalah prodak hukum yang pembetukannya didominasi oleh lembaga Negara, isinya bersifat positivistisinstrumentalistik dalam arti lebih mencerinkan kehendak sepihak penguasa, dan cakupannya bersifat opened interpretatif dalam arti bisa dengan mudah ditafsirkan secara sepihak oleh penguasa melalui pembuatan peraturan

33 Rusmadi Murad, 2013, Administrasi Pertanahan, Mandar Maju, Bandung, hlm. 343.

34 Achmad Sodiki, 2013, Politiki Hukum Agraria, Kompress, Jakarta, hlm. X. 
pelaksanaan berdasar kehendak pemerintah sendiri.

Itulah potret salah satu bukti nyata banyak dalam peraturan undang-undangan di negara Indonesia yang tumpang tindih, kabur dan tidak konsisten/ inkonsistensi dalam pelaksanaanya sehingga terjadi dissinkronisasi dalam praktek pelaksaannya hukum bahkan aturan pelaksanaanya tidak jelas, maka kelemahankelemahan/ kekaburan hukum terjadi, bila hal ini yang terjadi maka bagi pencari keadilan dan kemanfaatan serta kepastian hukum tidak akan tercapai bahkan terjadi cacat hukum.

Hal ini terjadi penyimpangan normative karena otentisitas akta-akta pertanahan dalam praktek hukum di Indonesia tidak dilakukan dilakukan oleh Notaris dengan pertimbangan fakta yuridis antara lain sebagai berikut: bahwa asas kebebasan berkontrak saat akta otentik P.P.J.B lunas dengan kuasa dibuat, sudah terjadi peralihan hak milik atas tanah secara absolute. Mutlak beralih menjadi milik pembeli, bahwa pembuatan aktaotentik P.P.J.B lunas dengan kuasa adalah kewenangan Notaris sebagai pejabat umum merupakan akta outentik berdasarkan Pasal 1 ayat (7) Undang-Undang Nomor 2 Tahun 2014 tentang jabatan Notaris (disebut U.U.J.N) sebagai implentasi dari Pasal 1868 K.U.H. Perdata, bahwa pejabat umum, dianalogikan dalam penafsiran analogis dengan kewenangannya sesuai Pasal 15 ayat (2) huruf f Undang-Undang Nomor 2 Tahun 2014 tentang jabatan Notaris, Notaris dapat membuat akta yang berkaitan dengan pertanahan, bahwa berdasarkan kekuatan hukum formil membuat akta P.P.J.B lunas dengan kuasa otentiknya berdasarkan undang-undang, sedangkan Akta Jual Beli (A.J.B) kekuatan hukum formilnya otentiknya dari peraturan Menteri.

Apabila disimak dari sudat pandang pada asas hukum, bahwa:

1. Berlakunya Undang-Undang yang dibuat oleh penguasa yang lebih tinggi mempunyai derajat yang lebih tinggi, sehingga apabila ada 2 (dua) macam undang-undang yang tidak sederajat mengatur objek yang sama dan saling bertentangan, maka hakim harus menerapkan undang-undang yang lebih tinggi dan menyatakan undang-undang yang lebih rendah tidak mengikat, asas lex superior derogat legi inferiori.

2. Asas lex priori derogate lex posteriori, undangundang yang berlaku kemudian membatalkan undang-undang yang terdahulu. ${ }^{35}$ Terkait dengan otentisitas akta, kewenangannya P.P.A.T. membuat akta otentik gugur demi hukum.

Peter Mahmud, mengemukakan bahwa: Asas hukum mempunyai arti penting bagi pembentukan hukum, penerapan hukum dan pengembangan ilmu hukum. Bagi pembentukan hukum, asasasas hukum memberikan landasan secara garis besar mengenai ketentuan-ketentuan yang perlu dituangkan di dalam aturan hukum. Di dalam penerapan hukum asas-asas hukum sangat membantu bagi digunakannya penafsiran dan penemuan hukum maupun analogi. Sedangkan bagi pengembangan ilmu hukum asas-asas hukum mempunyaikegunaan karena didalam asas-asas hukum dapat ditunjukkanberbagai aturan hukum yang pada tingkat yang lebih tinggi sebenarnya merupakan suatu ketentuan. ${ }^{36}$

Pembuatan akta otentik oleh Notaris landasan hukum (a) Undang- Undang Nomor 2 Tahun 2014 tentang Jabatan Notaris Pasal 1 ayat (1 dan 7) dan Pasal 1886 B.W., sedangkan (b) Peraturan Menteri Agraria/Kepala B.P.N. yang terkait dengan akta otentik jual beli P.P.A.T), inilah bukti fakta kekaburan hukum (insinkronisasi) yang mendasar yang dapat menimbulkan penafsiran hukum yang luas yang mengarah dissinkronisasi hukum. (c). Penunjukan P.P.A.T. sebagai pembuat akta-akta otentik di bidang pertanahan termasuk akta jual beli adalah bertentangan dengan Pasal 1868 B.W dan Pasal 1 ayat (1dan 7) Peraturan Jabatan Notaris Undang-Undang Nomor 2 Tahun 2014 tentang Jabatan Notaris. Terhadap akta-akta tanah yang dibuat P.P.A.T. tersebut atau yang oleh P.P. No. 37 tahun 1998 disebut dengan akta P.P.A.T., pembuatan akta-akta tanah yang di maksud jual beli yang dilakukan P.P.A.T. secara inplisit tidak diatur didalam Undang-Undang Nomor 5 35 J.B.Daliyo, S. dkk, Pengantar IImuHukum, Loc.Cit., hlm. 55.

36 Istislam, 2012, Sanksi Paksaan Pemerintah Dalam Perlindungan Dan Pengelolaan Lingkungan Hidup, Disertasi Pasca Sarjana Universitas Airlangga, hlm. 58. 
Tahun 1960 tentang Pokok-Pokok Agraria dan tidak secara tegas kewenangannya di dalam Peraturan Pemerintah Nomor 24 Tahun 1997 tentang Pendaftaran Tanah.

Kewenangannya dilakukan oleh Notaris, Undang-Undang Jabatan Notaris, seorang Notaris sebagai Pejabat Umum kewenangannya sesuai Undang-Undang Nomor 2 Tahun 2014 Pasal 15 ayat (2) huruf $f$, yaitu membuat akta yang berkaitan dengan pertanahan. ${ }^{37}$

Pembuatan partij akta menjadi kewenangan profesi Notaris diberi kewenangan dalam menuangkan kehendak para pihak selama tidak melanggar perundang-undangan hukum positif di negara kita dan dalam karakter yuridis akta Notaris sebagai salah satu alat bukti yaitu alat bukti tertulis yang mempunyai nilai pembuktian perkara pidana maupun perdata, sedangkan nilai pembuktian akta otentik mempunyai kekuatan pembuktian yang kuat yaitu:

1. Nilai pembuktian lahiriah (Uitwendige Bewijskracht) yaitu sudah sesuai dengan aturan hukum yang sudah ditentukan mengenai syarat akta otentik.

2. Formal (FormeleBewijskracht) bahwa sesuatu kejadian dan fakta tersebut dilakukan dalam akta benar-benar dilakukan oleh Notaris atau diterangkan oleh pihak-pihak yang menghadap yang tercantum dalam akta.

3. Materil (MaterieleBewijskracht), kepastian tentang materi suatu akta apa yang disebut dalam akta merupakan pembuktian yang sah terhadap pihak-pihak yang membuat akta disampaikan dan dituangkan dalam Partij akta.

Notaris bukan pihak dalam akta karena kewajiban menurut UUJN dalam setiap akta harus mencantumkan nama Notaris karena akta tersebut merupakan kehendak para penghadap yang minta kepada Notaris untuk membuat akta dan apabila para penghadap dan pihak lain yang bukan penghadap mempersoalkan akta tersebut tidak perlu menarik Notaris sebagai tergugat/turut tergugat atau terlapor, bahkan dianggap turut

37 Undang-Undang Nomor 30 Tahun 2004, Loc. Cit, hlm. 10. serta melakukan perbuatan sehingga terjerat atau dipidana sebagai membuat delik seperti yang dimaksud dalam Pasal 55 KUHP, kalau dipergunakan dalil pasal ini dikaitkan dengan kedudukan akta otentik maka ada indikasi adanya kriminalisaasi hukum, kecuali secara ekstrim Notaris sengaja untuk memenuhi kepentinagn pribadi seperti memasukkan keterangan palsu dalam akta otentik yang langsung berkaitan dengan minuta akta yang dilekatkan.

\section{Penutup.}

\section{Kesimpulan}

Menyimpang dari sisi hukum, jika ada para pihak yang namanya tersebut dalam akta atau pihak lain mendalilkan ada hak perdata mengajukan gugatan di Pengadilan dalam perkara perdata atau melaporkan ke Kepolisian dalam perkara pidana, maka telah menyalahi secara hukum disebut Kriminalisasi, karena Notaris yang jelasjelas bukan pihak dan hanya membuat akta atas kepentingan para pihak yang sesuai kewenangannya dalam Undang-Undang khususnya dalam membuat alat bukti tertulis atau otentik yang diakui oleh Negara

Notaris terikat dengan kebenaran formil apa-apa yang dituangkan dalam akta hanyalah data normatif tidak punya kewenangan membuktikan materiilnya, sehingga lembaga Pengadilan yang punya kewenangan tersebut.

Dalam Putusan Mahkamah Agung Nomor: 1642/K/Pdt/2005, bahwa dalam gugatan perdata seringkali diikutkan dalam gugatan perdata karena tidak lengkapan pihak tergugat sehingga berakibat error in persona/ kesalahan subjek hukum, maka gugatan tidak diterima/ Niet Ontvankelijkverklard.

Dalam putusan Mahkamah Agung Nomor: 702 K/K/Sip/1973, tanggal 5 September 1973, bahwa akta otentik yang deibuat Notaris sebagai akta pihak, jika para pihak bersengketa, maka Notaris tidak bisa dihukum.

Perlindungan hukum Notaris apabila dalam gugatan perdata tidak pernah hadir, maka dapat putusan Verstekapabila putusan tersebut merugikan Notaris, maka bisa mengajukan perlawanan Verzet. 


\section{DAFTAR PUSTAKA}

\section{BUKU}

Achmad Sodiki, 2013, Politiki Hukum Agraria, Kompress, Jakarta.

Boedi Harsono, 2008, Hukum Agraria Indonesia,Himpunan Peraturan-Peraturan Hukum Tanah, Djambatan, Jakarta.

Daliyo, dkk, 1994, Pengantar Ilmu Hukum, Gramedia Pustaka Utama, Jakarta.

Eddy Ruchiyat, 2006, Politik Pertanahan Nasional Sampai Orde Reformasi, Alumni, Bandung.

Habib Adjie, 2009, Sekilas Dunia Notaris \& P.P.A.T, Mondar Maju, Bandung. 2011, Hukum Notaris Indonesia, Refika Aditama, Bandung.

Munir Fuady, 1999, Hukum Kontrak, Citra Aditya Bakti, Bandung.

Mariam Darus Badrulzaman, dkk, 2001, Kompilasi Hukum Perikatan, Citra Aditya Bakti, Bandung.

Rusmadi Murad, 2013, Administrasi Pertanahan, Mandar Maju, Bandung.

Subekti, 1985, Aneka Perjanjian, Cetakan VII, Alumni Bandung. , 1990, Hukum Perjanjian, Inter Masa, Jakarta. 1995, Aneka Perjanjian, Citra Aditya Bakti, Bandung.

Suko Wiyono, 2010, Hukum Pertanahan, Bayumedia Publishing, Malang.

Subekti, 2008, Kitab Undang-Undang Hukum Perdata, Pradnya Paramita, Jakarta.

Subekti, 1993, Pokok-Pokok Hukum Perdata, T.Intermasa, Jakarta. Urip Santoso, 2012, Hukum Agraria, Kajian Komprehensif, Kencana Prenada Media Group, Jakarta.

Usni Thamrin, 2011, Pembuatan Akta Pertanahan Oleh Notaris, Laksbang Pressindo, Yogyakarta.

Wawan Muhwan Hariri, 2011, Hukum Perikatan, Pustaka Setia, Bandung. 